\title{
Initial Impact and Socioeconomic Compensation for the Closure of a Coal-Fired Power Plant in a Local Entity
}

\author{
Antonio Javier Prado-Domínguez ${ }^{1}$, Fernando González-Laxe ${ }^{1}$, Manuel Escourido-Calvo ${ }^{2}$ and \\ Federico Martín-Bermúdez ${ }^{1, *(D)}$ \\ 1 Department of Economics, A Coruña University, 15071 A Coruña, Spain; ajaprado@udc.es (A.J.P.-D.); \\ laxe@udc.es (F.G.-L.) \\ 2 Department of Business, A Coruña University, 15071 A Coruña, Spain; manuel.escourido@udc.es \\ * Correspondence: federico.martin@udc.es
}

Citation: Prado-Domínguez, A.J.; González-Laxe, F.; Escourido-Calvo, M.; Martín-Bermúdez, F. Initial Impact and Socioeconomic Compensation for the Closure of a Coal-Fired Power Plant in a Local Entity. Sustainability 2021, 13, 7391. https://doi.org/10.3390/su13137391

Academic Editor: Chiara D'Alpaos

Received: 1 June 2021

Accepted: 25 June 2021

Published: 1 July 2021

Publisher's Note: MDPI stays neutral with regard to jurisdictional claims in published maps and institutional affiliations.

Copyright: (c) 2021 by the authors. Licensee MDPI, Basel, Switzerland. This article is an open access article distributed under the terms and conditions of the Creative Commons Attribution (CC BY) license (https:/ / creativecommons.org/licenses/by/ $4.0 /)$.

\begin{abstract}
This work contributes to improving the relevant information for the local participatory process, in a context of just energy transition. A proposal has been prepared for an objective estimate of the initial impact and the minimum socioeconomic compensation for the closure of a conventional coal-fired thermal power plant in the affected local entity. This has allowed (1) specifying and contextualizing the effects into which the initial impact of the closure can be divided, with the inclusion of the circular effect; (2) obtaining an indicator of the minimum compensation that would need to be set to neutralize this impact; and (3) establishing recommendations and conclusions based on the evidence obtained.
\end{abstract}

Keywords: coal power plant closure; just energy transition; participatory process; initial impact; local compensation; multilevel informational outlook

\section{Introduction}

Energy transition processes are often unique, slow and generally driven by a combination of factors, not always predictable and manageable in the short term, which end up revealing common effects on and challenges for concerned territories [1]. This makes it useful to consider them in their historical contexts in order to draw transferable lessons to study how they might develop in the future [2-4].

Transition processes are complex, as nonspecialized actors suffer from a situation similar to that posed by the "veil of ignorance", due to lack of access to costly and relevant information. It happens, then, that those affected cannot successfully overcome the complexity in a self-taught manner and require reliable explanations and verification that they have adequately understood the relevant information to overcome this "veil of ignorance". Hence, it is important that energy transitions emphasize fully informed participatory processes of citizens in general, and affected individuals and groups in particular, in order to achieve authentically fair regulatory change in a Rawlsian sense [5].

The objective that the transition must be just means not only that it must actively promote compensation and redress for damages, but also that it must implement measures to ensure that those affected are supported through a full and consensual participatory process. They later must have the possibility to influence and decide how and when measures are to be taken.

Those affected will therefore need to be fully informed in order to have a real capacity to present and negotiate alternatives, both for redress and for the formulation of new, complementary or substitute options that will continue to secure the main economic base of the affected territory and its inhabitants [4].

Our work aims to contribute to this objective of full information with a proposal for an objective estimate of the initial impact of the closure of the largest conventional coal-fired thermal power plant in Spain on the economy and employment of the municipality in which 
it is located. We propose a suitable methodology to contextualize and specify the effects into which the initial impact of the closure can be divided, including the circular effect. With this information, it is possible to obtain an indicator of the minimum compensation that would be necessary to neutralize this impact, based on the internal absorption of income by that territory of the total production carried out there.

Moreover, it is helpful for policies designed to accelerate the closure of coal-fired power plants to stop including references to the need for a "just" transition that encourages sustainability and circularity in affected communities, devoid of sufficient compensatory content (in line with that indicated by Atteridge and Strambo [1]).

To overcome this deficiency, our contribution proposes the specification of an objective instrument to quantify compensation in terms of income and employment for the affected territory. Not having such objective tools prevents any participatory process from overcoming the "veil of ignorance". In other words, there would not be the necessary instruments to generate effective information, which avoids the enshrinement of the lack of transparency in the decision-making process, as the latter remains out of public scrutiny.

In such a case, there would be a serious risk that strategic frameworks would be formed that marginalize local interests, misrepresent the diagnosis, exacerbate the lack of local empowerment and even allow the redistribution of financing to other territories that are not directly affected by the imminent closure of coal-fired power plants [6].

Finally, the information obtained highlights that the guarantee of an authentic "just transition" in the case of study is entrusted to an integrated set of policies and effective multilevel governance, which, in Spain, will be implemented through the Just Transition Conventions (CTJ) [7]. These instruments address multilevel (in the case of study, multilevel governance refers to the European Commission (European Union), the Spanish central government and Xunta de Galicia, regional government)) governance in a comprehensive manner so that it can be involved in the implementation of public policies to correct the first negative impact on the territory and its residents and specific measures for its long-term economic and environmental sustainability $[1,7,8]$.

\section{Estimation Methodology}

The As Pontes Thermal Power Station (map and information panel) (Figure 1) belongs to Endesa, a subsidiary of the Italian company Enel, whose majority shareholder is the Italian state, which operates like any other private investor in the capital of foreign companies in the energy sector.

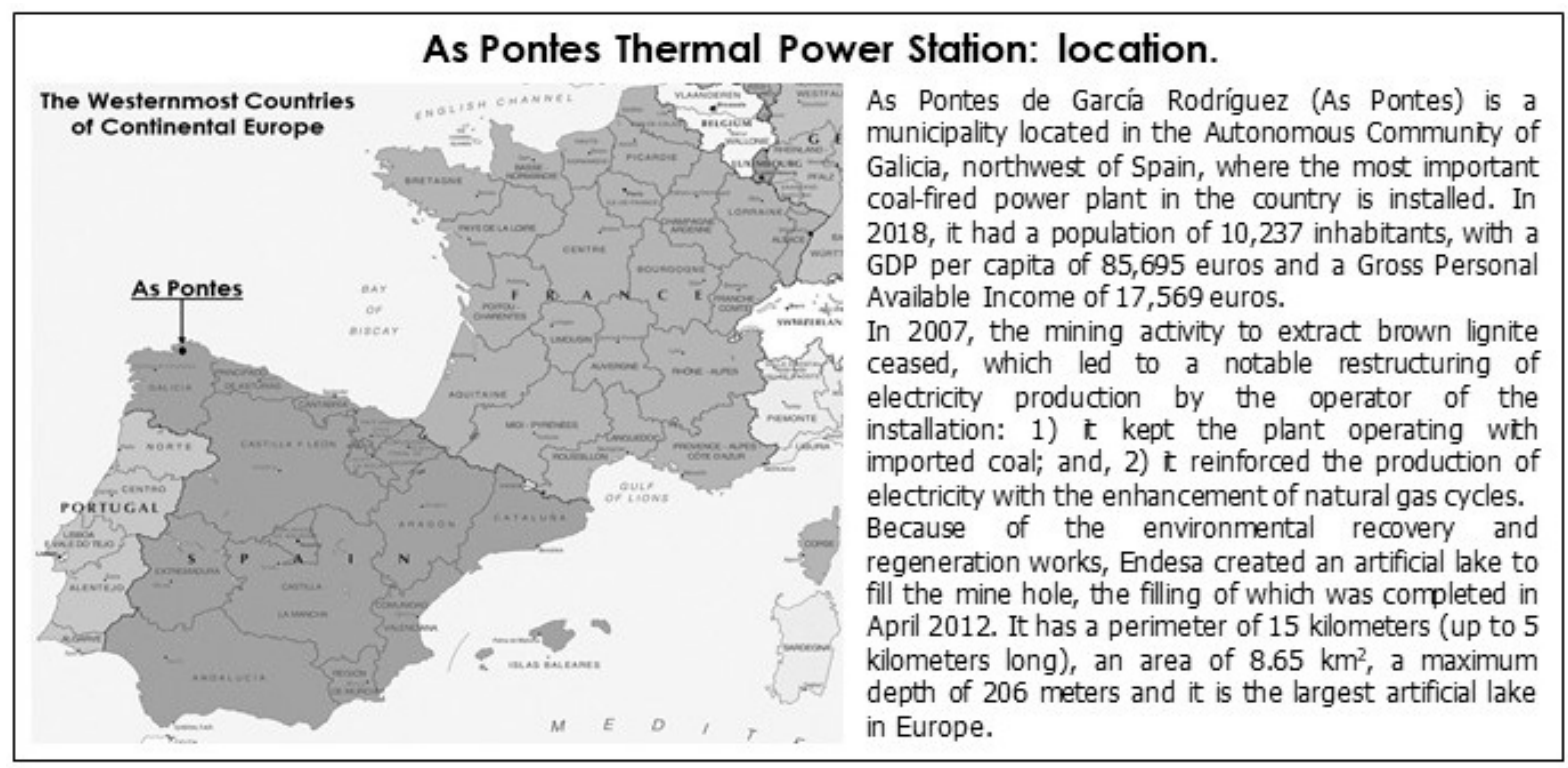

Figure 1. Own elaboration. 
As a whole, the plant is the largest electricity production unit in Spain and consists of three types of production facilities:

a. A conventional coal plant, the largest in Spain, made up of four units and with a total gross installed capacity of $1468.5 \mathrm{MW}$. These are the units affected by the closure, which constitutes the case study.

b. A natural gas combined cycle thermal power plant with a gross installed capacity of 855.0 MW.

c. Two hydroelectric power plants with a gross installed capacity of $60 \mathrm{MW}$ and one wind power plant with a gross installed capacity of $161 \mathrm{MW}$. The current estimate of the expansion potential of renewable energies is an additional 1918.7 MW, highlighting the potential contributions of wind energy with $437 \mathrm{MW}$ and photovoltaic with 1434.7 MW.

\subsection{Sources and Statistical Data Used}

To determine the impact of the closure of the coal-fired power plant, we used several mutually compatible sources of information. Firstly, we used information on production, branches of activity, gross value added (GVA) and its components in the municipality of As Pontes, where the coal plant affected by the closure is located. This information, summarized in Table 1, was provided by the Galician Statistics Institute (IGE) for 2018, the latest official data available [9]. The data in this table confirm energy activity as an industrial monoculture in the economic structure of the municipality, accounting for $76.8 \%$ of production, $79.0 \%$ of intermediate consumption and $74.0 \%$ of local GVA.

Secondly, we used the statistical data, referring to January 2019, provided by Endesa, descriptive technical data on the installation itself and relevant economic and employment information from the company itself.

Finally, we used the results of a survey carried out among the local population and data from questionnaires and forms obtained from a field study carried out ad hoc for our research among the groups affected by the closure: (1) auxiliary companies, coal transporters, commerce and the hotel industry and (2) trade unions and professionals. On a tabulated sample, according to gender and age criteria, of 401 people between 20 and 74 years old, six months after the announcement of the closure, between July 1 and 4,2020 , we conducted a survey made up of a total of 45 questions, divided into seven sections: (1) information, governance and trust (7 questions); (2) concerns and social repercussions (7 questions); (3) community values (4 questions); (4) effects on the standard of living (4 questions); (5) economic opportunities and expectations (9 questions); (6) citizen awareness (4 questions); (7) socioeconomic information (10 questions). We processed the articulation of all this information with the specification and analysis of a SEM model, the results of which support the great importance given to the role of the participatory process in this work. Confidence level: $95 \%$. Margin of error: $5 \%$.

Due to local interest in the subject of the survey, there was no rejection among the participants, so this parameter turned out to be much lower than that registered by the references we have cited. In general, we will say that the issue of the closure generates in the population of As Pontes great concern and uncertainty of which they have wanted to speak, for the most part, at length. The option "Does not know/Does not answer" was chosen, on average, in $1.02 \%$ of cases. The respondents answered and/or knew what to answer in $98.98 \%$ of the cases. Therefore, the uncertainty about the results obtained is not statistically significant.

Lastly, no significant change should be noted to date in relation to the evidence provided by our work regarding the development of the participatory process in As Pontes. 
Table 1. Accounts of production, intermediate consumptions and gross value added, by activity branches. As Pontes City Council, 2018 (in millions of euros).

\begin{tabular}{|c|c|c|c|c|c|c|c|c|c|c|c|c|c|}
\hline $\begin{array}{l}\text { Starting Situation Open } \\
\text { Thermal Power Plant }\end{array}$ & Total & $\begin{array}{l}\text { Primary } \\
\text { Sector }\end{array}$ & $\begin{array}{l}\text { Agrifood } \\
\text { Industry }\end{array}$ & $\begin{array}{l}\text { Wood, } \\
\text { Paper and } \\
\text { Furniture }\end{array}$ & $\begin{array}{c}\text { Extractive } \\
\text { Industries and } \\
\text { Manufacture of } \\
\text { Other } \\
\text { Nonmetallic } \\
\text { Mineral } \\
\text { Products }\end{array}$ & $\begin{array}{c}\text { Metal, } \\
\text { Electronic } \\
\text { and Electrical } \\
\text { Products and } \\
\text { Machinery }\end{array}$ & $\begin{array}{c}\text { Manufacture } \\
\text { of Transport } \\
\text { Equipment } \\
\text { and Large } \\
\text { Industrial } \\
\text { Repairs }\end{array}$ & $\begin{array}{l}\text { Rest of } \\
\text { Industry }\end{array}$ & $\begin{array}{c}\text { Energy, } \\
\text { Water Supply } \\
\text { and Waste } \\
\text { Management }\end{array}$ & Building & $\begin{array}{c}\text { Commerce, } \\
\text { Transport } \\
\text { and } \\
\text { Hospitality }\end{array}$ & $\begin{array}{c}\text { Information, } \\
\text { Financial, } \\
\text { Real Estate, } \\
\text { Health and } \\
\text { Professional } \\
\text { Activities }\end{array}$ & $\begin{array}{c}\text { Public Ad- } \\
\text { ministration, } \\
\text { Education, } \\
\text { Health and } \\
\text { Other } \\
\text { Services }\end{array}$ \\
\hline Production & 1885.6 & 14.8 & 14.0 & 29.4 & 1.1 & 33.5 & 56.5 & 37.7 & 1448.2 & 41.8 & 94.7 & 59.2 & 54.7 \\
\hline Intermediate Consumptions & 1054.0 & 7.8 & 10.7 & 22.2 & 0.8 & 21.4 & 30.1 & 23.5 & 832.7 & 21.0 & 49.8 & 18.4 & 15.6 \\
\hline Gross Value Added (GVA) & 831.6 & 7.0 & 3.3 & 7.2 & 0.03 & 12.1 & 26.3 & 114.2 & 615.5 & 20.8 & 45.0 & 40.8 & 39.1 \\
\hline Net Taxes on Products & 35.2 & & & & & & & & & & & & \\
\hline Gross Domestic Product (GDP) & 866.8 & & & & & & & & & & & & \\
\hline
\end{tabular}


2.2. Delimitation of the Losses Recorded in the Economy and Employment in the Municipality of As Pontes: Methodology and Data Cleaning

The first step taken to achieve this objective was the depuration of the "energy, water supply and waste management" branch of activity in order to bring the part corresponding to the coal-fired power plant to the surface. This facility consists of four groups, with a total gross installed capacity of $1468.5 \mathrm{MW}$, giving 2544.5 MW for the entire complex.

Therefore, $57.71 \%$ (1468.5 MW) corresponds to the conventional coal-fired thermal power station, and this was the coefficient chosen as the weighting of the participation of the coal-fired thermal installation in the branch of activity that encompasses the whole of the municipality's energy sector.

However, the figure resulting from the above adjustment also needed to be refined as most of the coal plant's production is destined for sale or marketing outside the municipality. This led to the second step of the estimation, in order to delimit the internal absorption of the production of this power plant in the municipality. The chosen method, due to the availability of data, was that of income. Based on the reported data, we calculated the loss of income in the affected activities as the sum of the salary of resident workers and the income of properties and companies.

The choice of this approach made it possible to calculate the losses caused in GVA and its components. Subsequently, with the data on gross annual wages from the direct sources available for each of the branches of activity, it was possible to obtain the loss of employment that was attributable to the direct effect (caused by the main endogenous activity) and the indirect effect (originating from secondary endogenous activity).

\subsection{Procedure to Determine the Circular Effect of the Plant Closure}

A proper contextualization of the direct and indirect effects caused by the closure of the coal plant would be incomplete without the calculation of the circular effect and its components. The circular effect originates from the influence of the endogenous industries on the rest of the exogenous industries. Only with the consideration of the three effects is the entire circular flow of income addressed, which will no longer be obtained internally by the As Pontes economy, due to the closure.

For this purpose, we used the methodology of the social accounting matrix [10,11]. This instrument is a flexible extension of the input-output matrix and is appropriate for analyzing the socioeconomic impacts of different economic policies in specific settings. To do this, we built an extended TIO matrix $(16 \times 16)$ to determine the circular effect of the case study.

We prepared this matrix with the coefficients of the extended regional IOT provided by the IGE and maintaining the existing proportionality between the regional aggregates and the municipal branches of activity. This construction was adapted to the informative particularities mentioned above in order to improve the estimation of the circular effect in As Pontes.

The proposed methodology makes it possible to obtain objective indicators of the total impact of the closure and the breakdown of its partial effects: (1) direct (quantification of the loss caused by the closure of the main endogenous activity corresponding to the plant itself), (2) indirect (assessment of the loss of GVA and income due to the cessation of the secondary endogenous activities carried out by the auxiliary companies and the transporters of the coal supply to the plant, and (3) circular (which includes the rest of the economic activities, other than the above, that make up the matrix).

Next, we indicate how we obtained the particular algebraic relationships to quantify each of the effects in the specific case [11]. Before validating the estimation of the circular effect, it was checked that the quantification of the direct and indirect effects by the procedure chosen was the same as that obtained from the data on gross wages and the workforce provided by the reporting firms.

In order to determine the circular effect, without loss of generality and for reasons of simplification, it was assumed that the extended TIO matrix of As Pontes would be 
made up of six accounts: $y_{1}, y_{2}, y_{3}, \ldots, y_{6}$. These include the branches of activity of the input-output matrix and the accounts representing the labor factor and the income of capital and companies.

Consequently, the following table gives the representation of the flows between these accounts:

$\begin{array}{lcccccc} & y_{1} & y_{2} & y_{3} & y_{4} & y_{5} & y_{6} \\ y_{1} & y_{11} & y_{12} & y_{13} & y_{14} & y_{15} & y_{16} \\ y_{2} & y_{21} & y_{22} & y_{23} & y_{24} & y_{25} & y_{26} \\ y_{3} & y_{31} & y_{32} & y_{33} & y_{34} & y_{35} & y_{36} \\ y_{4} & y_{41} & y_{42} & y_{43} & y_{44} & y_{45} & y_{46} \\ y_{5} & y_{51} & y_{52} & y_{53} & y_{54} & y_{55} & y_{56} \\ y_{6} & y_{61} & y_{62} & y_{63} & y_{64} & y_{65} & y_{66}\end{array}$

In the table above, each entry $y_{i j}$ indicates the amount that account $i$ receives from account $j$. From here, we can obtain the matrix $A=\left(a_{i j}\right)$, where $a_{i j}=\frac{y_{i j}}{y_{j}}$ are the payments to account $i$ per unit of income of account $j$ :

$$
A=\left(\begin{array}{ccc}
\frac{y_{11}}{y_{11}+y_{21}+\ldots+y_{61}} & \cdots & \frac{y_{16}}{y_{16}+y_{26}+\ldots+y_{66}} \\
\vdots & & \\
\frac{y_{61}}{y_{11}+y_{21}+\ldots+y_{61}} & \cdots & \frac{y_{66}}{y_{16}+y_{26}+\ldots+y_{66}}
\end{array}\right)
$$

which allows the following matrix equation to be written:

$$
\left(\begin{array}{l}
y_{1} \\
y_{2} \\
y_{3} \\
y_{4} \\
y_{5} \\
y_{6}
\end{array}\right)=\left(\begin{array}{llllll}
a_{11} & a_{12} & a_{13} & a_{14} & a_{15} & a_{16} \\
a_{21} & a_{22} & a_{23} & a_{24} & a_{25} & a_{26} \\
a_{31} & a_{32} & a_{33} & a_{34} & a_{35} & a_{36} \\
a_{41} & a_{42} & a_{43} & a_{44} & a_{45} & a_{46} \\
a_{51} & a_{52} & a_{53} & a_{54} & a_{55} & a_{56} \\
a_{61} & a_{62} & a_{63} & a_{64} & a_{65} & a_{66}
\end{array}\right)\left(\begin{array}{l}
y_{1} \\
y_{2} \\
y_{3} \\
y_{4} \\
y_{5} \\
y_{6}
\end{array}\right)
$$

Generally, $Y=A \cdot Y$.

The accounts are now divided into two types: endogenous and exogenous, with endogenous accounts being those related to the operation of the coal plant $y_{1}, y_{2}, y_{3}, y_{4}$. If endogenous and exogenous activities are separated, the above matrix equation can be rewritten as follows:

$$
\left(\begin{array}{l}
y_{1} \\
y_{2} \\
y_{3} \\
y_{4}
\end{array}\right)=\left(\begin{array}{llll}
a_{11} & a_{12} & a_{13} & a_{14} \\
a_{21} & a_{22} & a_{23} & a_{24} \\
a_{31} & a_{32} & a_{33} & a_{34} \\
a_{41} & a_{42} & a_{43} & a_{44}
\end{array}\right)\left(\begin{array}{l}
y_{1} \\
y_{2} \\
y_{3} \\
y_{4}
\end{array}\right)+\left(\begin{array}{ll}
a_{15} & a_{16} \\
a_{25} & a_{26} \\
a_{35} & a_{36} \\
a_{45} & a_{46}
\end{array}\right)\left(\begin{array}{l}
y_{5} \\
y_{6}
\end{array}\right)
$$

In abbreviated and generalized form

$$
Y_{m}=A_{m} \cdot Y_{m}+A_{m k} \cdot Y_{k}
$$

in which

$$
\begin{gathered}
Y_{m}-A_{m} Y_{m}=A_{m k} Y_{k} \\
\left(I-A_{m}\right) Y_{m}=A_{m k} Y_{k} \\
Y_{m}=\underbrace{\left(I-A_{m}\right)^{-1}}_{M} \cdot \underbrace{A_{m k} Y_{k}}_{Z} \\
Y_{m}=M \cdot Z
\end{gathered}
$$

If the changes in the exogenous accounts are called $d Z$, then,

$$
d Y_{m}=M \cdot d Z=M \cdot d\left(A_{m k} Y_{k}\right)=M \cdot A_{m k} \cdot d Y_{k}
$$


If in Equation (3), $A_{m k} \cdot Y_{k}$ is substituted by $Z$, we obtain

$$
Y_{m}=A_{m} \cdot Y_{m}+Z
$$

Then, the matrix of order $m$ is called $A_{m}^{\prime}$ in which all its elements are zeros, except those of the rows and columns corresponding to the productive activities, which coincide with the matrix $A_{m}$. In this case,

$$
A_{m}=\left(\begin{array}{llll}
a_{11} & a_{12} & a_{13} & a_{14} \\
a_{21} & a_{22} & a_{23} & a_{24} \\
a_{31} & a_{32} & a_{33} & a_{34} \\
a_{41} & a_{42} & a_{43} & a_{44}
\end{array}\right)
$$

Being the productive activities 1 and 3 , the following would be obtained:

$$
A_{m}^{\prime}=\left(\begin{array}{cccc}
a_{11} & a_{12} & a_{13} & a_{14} \\
a_{21} & 0 & a_{23} & 0 \\
a_{31} & a_{32} & a_{33} & a_{34} \\
a_{41} & 0 & a_{43} & 0
\end{array}\right)
$$

Adding and subtracting $A_{m}$ in Equation (5), gives the expression

$$
Y_{m}=\left(A_{m}-A_{m}^{\prime}\right) Y_{m}+A_{m}^{\prime} \cdot Y_{m}+Z
$$

in which

$$
\begin{gathered}
Y_{m}-A_{m}^{\prime} \cdot Y_{m}=\left(A_{m}-A_{m}^{\prime}\right) Y_{m}+Z \\
\left(I-A_{m}^{\prime}\right) Y_{m}=\left(A_{m}-A_{m}^{\prime}\right) Y_{m}+Z \\
Y_{m}=\underbrace{\left(I-A_{m}^{\prime}\right)^{-1} \cdot\left(A_{m}-A_{m}^{\prime}\right)}_{A^{*}} \cdot Y_{m}+\left(I-A_{m}^{\prime}\right)^{-1} \cdot Z \\
Y_{m}=A^{*} \cdot Y_{m}+\left(I-A_{m}^{\prime}\right)^{-1} \cdot Z
\end{gathered}
$$

If multiplied by

$$
A^{*}: A^{*} \cdot Y_{m}=A^{*^{2}} \cdot Y_{m}+A^{*} \cdot\left(I-A_{m}^{\prime}\right)^{-1} \cdot Z
$$

From Equation (7), we can obtain $A^{*} \cdot Y_{m}$ :

$$
A^{*} \cdot Y_{m}=Y_{m}-\left(I-A_{m}^{\prime}\right)^{-1} \cdot Z
$$

Substituting in the expression (8),

$$
\begin{gathered}
Y_{m}-\left(I-A_{m}^{\prime}\right)^{-1} \cdot Z=A^{*^{2}} \cdot Y_{m}+A^{*}\left(I-A_{m}^{\prime}\right)^{-1} \cdot Z \\
Y_{m}=A^{*^{2}} Y_{m}+\left(I-A_{m}^{\prime}\right)^{-1} \cdot Z+A^{*}\left(I-A_{m}^{\prime}\right)^{-1} \cdot Z \\
Y_{m}=A^{*^{2}} Y_{m}+\left(I+A^{*}\right) \cdot\left(I-A_{m}^{\prime}\right)^{-1} \cdot Z
\end{gathered}
$$

That is to say,

$$
Y_{m}=A^{*^{2}} Y_{m}+\left(I+A^{*}\right) \cdot\left(I-A_{m}^{\prime}\right)^{-1} \cdot Z
$$

The process is repeated, multiplying by $A^{*}$ :

$$
A^{*} \cdot Y_{m}=A^{*^{3}} \cdot Y_{m}+A^{*}\left(I+A^{*}\right)\left(I-A_{m}^{\prime}\right)^{-1} \cdot Z
$$


Now, $A^{*} Y_{m}$ is replaced by $Y_{m}-\left(I-A_{m}^{\prime}\right)^{-1} \cdot Z$ :

$$
\begin{gathered}
Y_{m}-\left(I-A_{m}^{\prime}\right)^{-1} \cdot Z=A^{*^{3}} Y_{m}+A^{*}\left(I+A^{*}\right)\left(I-A_{m}^{\prime}\right)^{-1} \cdot Z \\
Y_{m}=A^{*^{3}} Y_{m}+\left(I-A_{m}^{\prime}\right)^{-1} \cdot Z+A^{*}\left(I+A^{*}\right)\left(I-A_{m}^{\prime}\right)^{-1} \cdot Z \\
Y_{m}=A^{*^{3}} Y_{m}-\left(I-A_{m}^{\prime}\right)^{-1} \cdot Z+A^{*}\left(I+A^{*}\right)\left(I-A_{m}^{\prime}\right)^{-1} \cdot Z \\
\left(I-A^{*^{3}}\right) Y_{m}=\left(I+A^{*}\left(I+A^{*}\right)\right)\left(I-A_{m}^{\prime}\right)^{-1} \cdot Z \\
Y_{m}=\underbrace{\left(I-A^{*^{3}}\right)^{-1}}_{M_{3}} \cdot \underbrace{\left(I+A^{*}+A^{*^{2}}\right)}_{M_{2}} \cdot \underbrace{\left(I-A_{m}^{\prime}\right)^{-1}}_{M_{1}} \cdot Z \\
Y_{m}=M_{3} \cdot M_{2} \cdot M_{1} \cdot Z
\end{gathered}
$$

In Equation (10) above (11):

- $\quad M_{1}=\left(I-A_{m}^{\prime}\right)^{-1}$ is the term that includes any direct effect caused by intra-activity transfers. It therefore allows the effect on a specific account of an exogenous detraction such as that due to plant closure to be quantified.

- $\quad M_{2}=\left(I+A^{*}+A^{* 2}\right)$ is the term that makes it possible to quantify the indirect effects originating in an exogenous income detraction on the other endogenous secondary accounts of the main one.

- $\quad M_{3}=\left(I-A^{* 3}\right)^{-1}$ is the term that allows us to collect the set of induced effects that originate from the existence of feedback in the circular flow of income of a specific economy such as that of As Pontes. Not to consider this effect in a transition process is to deliberately underestimate the effects of a closure and, therefore, to renounce to a fair process.

From Equation (4), it follows that

$$
M=M_{3} \cdot M_{2} \cdot M_{1}
$$

from where

$$
\begin{aligned}
& I+\left(M_{1}-I\right)+\left(M_{2}-I\right) \cdot M_{1}+\left(M_{3}-I\right) M_{2} M_{1} \\
& =I+M_{1}-I+M_{2} \cdot M_{1}-M_{1}+M_{3} \cdot M_{2} \cdot M_{1}-M_{2} \cdot M_{1} \\
& =M_{3} \cdot M_{2} \cdot M_{1}
\end{aligned}
$$

This allows the following expression to be established:

$$
M=M_{1} \cdot M_{2} \cdot M_{3}=I+\left(M_{1}-I\right)+\left(M_{2}-I\right) M_{1}+\left(M_{3}-I\right) M_{2} M_{1}
$$

and, as it is fulfilled that

$$
N_{1}=M_{1}-I ; N_{2}=\left(M_{2}-I\right) M_{1} ; N_{3}=\left(M_{3}-I\right) M_{2} M_{1}
$$

$M=I+N_{1}+N_{2}+N_{3}$ is obtained.

Otherwise,

$$
M-I=N_{1}+N_{2}+N_{3}
$$

From the above equality, it is possible to derive the total impact as the sum of three distinct but closely related economic effects:

- $\quad M-I$ represents the total net multiplier effect. In this case, this is the total effect on the economy of As Pontes of the closure of the four groups of the conventional coal-fired thermal power plant.

- $\quad N_{1}=M_{1}-I$ is the direct net effect, which includes the impact of the aforementioned closure on the main endogenous production activities of Endesa's coal-fired thermal plant. In this case, the quantification in this way and that obtained from the company's 
data coincide and give a percentage value of this effect of $9.17 \%$ of the total impact. This percentage coincides with that derived from the data reported by Endesa.

- $\quad N_{2}=\left(M_{2}-I\right) M_{1}$ is the net indirect effect, which includes the impact of the closure on the other endogenous accounts, or secondary endogenous activities: auxiliary companies and coal transporters. The resolution of the above expression allows the value of the indirect impact to be put at $27.76 \%$ of the total impact. This percentage is 3.12 percentage points higher than that derived from the data of the companies due to the consideration of including the specific transport of coal supply to the plant in this group.

- $\quad N_{3}=\left(M_{3}-I\right) M_{2} M_{1}$ is the net circular or induced effect, which reflects the impact of the cessation of endogenous activities on exogenous activities. In this case, the value of this effect is $63.07 \%$ of the total impact caused by the closure in As Pontes. Therefore, not considering this effect implies that the transition process is not neutral as it ignores the chain effects that occur on the variables of the circular flow of income of a territory when it suffers an intense negative shock, as in the case study.

Finally, we consider that our proposal provides an enriching element, which allows us to specify and contextualize the phenomenon of the closure of this or any other coal-fired power plant in terms of the internal circular flow of income of the territory affected. This is very significant because in any territory, together with endogenous activities, other exogenous activities are produced, which are of great importance not only for income, employment or GDP, but also for achieving environmental or demographic sustainability objectives.

\section{The Impact of the Closure of the Coal Plant on the Economy and Employment in As Pontes}

In the Spanish case, the government has foreseen that the CTJs can act as a compensation instrument with which to mitigate the negative impacts generated by the energy and ecological transition process, to the extent that they are configured as an integrated set of policies and effective multilevel governance [7].

The types of impacts are defined in the Urgent Action Plan included in the Just Transition Strategy, which addresses short-term challenges in areas affected by the closure of mines, coal power plants and nuclear power plants.

The Plan establishes that the CTJs should aim to ensure that closures do not have a negative impact on employment and the population at the end of the process. By having employment as a fundamental indicator, the CTJs are a key tool for the reactivation of territories with energy monocultures, such as As Pontes, where the energy and ecological transition can put companies and economic activity in difficult situations.

In the following sections of this paper, we proceed to estimate the impact that the closure of Endesa's coal-fired power plant, requested in December 2019, will have on employment, GVA and its components in the municipality of As Pontes, based on the latest official data available for 2018.

\subsection{Quantification of the Losses in the Economy and Employment as a Result of the Request to Close the Plant}

The results obtained by applying the procedure described in Section 2.3 are shown in Table 2. These constitute the estimate of the impact of the closure of the coal plant on each of the branches of activity and on the production accounts and their components, expressed in thousands of euros and current prices. The statistical perspective used is that of internal income absorption, which has turned out to be more suitable for evaluating the effects of the initial impact than GDP in the conventional and broad sense. Failure to depurate the conventional aggregates would lead to an underestimation of the negative internal effects in the affected territory. 


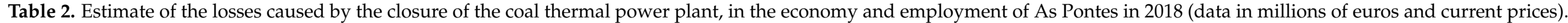

\begin{tabular}{|c|c|c|c|c|c|c|c|c|c|c|c|c|c|}
\hline $\begin{array}{l}\text { Quantification of Losses Due to the Closing of } \\
\text { the Thermal Power Plant }\end{array}$ & Total & $\begin{array}{l}\text { Primary } \\
\text { Sector }\end{array}$ & $\begin{array}{l}\text { Agrifood } \\
\text { Industry }\end{array}$ & $\begin{array}{c}\text { Wood, } \\
\text { Paper and } \\
\text { Furniture }\end{array}$ & $\begin{array}{c}\text { Extractive } \\
\text { Industries } \\
\text { and } \\
\text { Manufacture } \\
\text { of Other } \\
\text { Nonmetallic } \\
\text { Mineral } \\
\text { Products }\end{array}$ & $\begin{array}{c}\text { Metal, } \\
\text { Electronic } \\
\text { and } \\
\text { Electrical } \\
\text { Products } \\
\text { and } \\
\text { Machinery }\end{array}$ & $\begin{array}{c}\text { Manufacture } \\
\text { of } \\
\text { Transport } \\
\text { Equipment } \\
\text { and Large } \\
\text { Industrial } \\
\text { Repairs }\end{array}$ & $\begin{array}{l}\text { Rest of } \\
\text { Industry }\end{array}$ & $\begin{array}{c}\text { Energy, } \\
\text { Water Supply } \\
\text { and Waste } \\
\text { Management }\end{array}$ & Building & $\begin{array}{c}\text { Commerce, } \\
\text { Transport } \\
\text { and } \\
\text { Hospitality }\end{array}$ & $\begin{array}{c}\text { Information, } \\
\text { Financial, } \\
\text { Real Estate, } \\
\text { Health and } \\
\text { Professional } \\
\text { Activities }\end{array}$ & $\begin{array}{c}\text { Public } \\
\text { Adminis- } \\
\text { Tration, } \\
\text { Education, } \\
\text { Health and } \\
\text { Other } \\
\text { Services }\end{array}$ \\
\hline \multicolumn{14}{|l|}{ In the Economy: } \\
\hline Production & 144.3 & 4.3 & 4.2 & 8.8 & 0.3 & 9.9 & 16.4 & 11.1 & 17.3 & 12.1 & 27.6 & 16.8 & 15.5 \\
\hline Intermediate Consumptions & 77.3 & 2.4 & 3.3 & 6.8 & 0.2 & 6.6 & 9.2 & 7.2 & 9.8 & 6.4 & 15.2 & 5.6 & 4.8 \\
\hline Gross Value Added (GVA) & 66.7 & 1.9 & 0.9 & 1.9 & 0.1 & 3.3 & 7.2 & 3.9 & 7.5 & 5.7 & 12.4 & 11.2 & 10.7 \\
\hline Property and Business Incomes & 33.2 & 1.4 & 0.1 & 1.8 & 0.0 & 0.8 & 4.2 & -0.1 & 2.7 & 3.8 & 0.6 & 9.9 & 8.0 \\
\hline \multicolumn{14}{|l|}{ In Employment: } \\
\hline Salary Remunerations & 33.6 & 0.05 & 0.8 & 0.1 & 0.1 & 2.5 & 3.0 & 4.1 & 4.9 & 11.9 & 11.7 & 1.2 & 2.8 \\
\hline Salary Remunerations per Job (employees) & 0.029 & 0.020 & 0.028 & 0.032 & 0.032 & 0.032 & 0.031 & 0.032 & 0.045 & 0.027 & 0.023 & 0.028 & 0.031 \\
\hline Number of Jobs Eliminated (employees) & 1178 & 24 & 29 & 4 & 4 & 77 & 96 & 126 & 108 & 71 & 504 & 45 & 90 \\
\hline
\end{tabular}

Source: own elaboration, based on the estimate made following the procedure described in Section 2, with data from the IGE (2019, Statistical Review), Endesa, workers unions and business associations. 
With no compensation policies or substitute economic activity, the expected annual losses due to the initial impact (in current euros and as a percentage of the total internal absorption of each of the respective variables) (Table 2), would be as follows:

(1) Production $=$ EUR $-144.3 \mathrm{MM}$ and $-49.2 \%$.

(2) Intermediate Consumption $=\mathrm{EUR}-77.5 \mathrm{MM}$ and $-52.6 \%$.

(3) $\mathrm{GVA}=\mathrm{EUR}-66.7 \mathrm{MM}$ and $-45.5 \%$.

(4) Salary Remunerations $=$ EUR $-33.6 \mathrm{MM}$ and $-44.3 \%$.

(5) Property and Business Income $=$ EUR $-33.1 \mathrm{MM}$ and $-46.6 \%$

In terms of employment, the breakdown of partial losses by branch of activity and the aggregate loss of employment, which would amount to 1178 resident jobs, is given.

The expected loss of employment is completed with Table 3, which provides information on the relative impact of the closure on some of the main variables of the local labor market.

Table 3. Impact of the closure on the main variables of the As Pontes labor market: year 2018.

\begin{tabular}{ccccccc}
\hline & & Direct Effect & Indirect Effect & Induced Effect & Total Effect \\
\cline { 2 - 6 } & Before & Loss of 108 Jobs & Loss of 327 Jobs & Loss of 743 Jobs & Loss of 1178 Jobs \\
\cline { 2 - 6 } & Closing & Impact (\%) & Impact (\%) & Impact (\%) & Impact (\%) \\
\hline Resident Active Population & 4674 & 2.3 & 7.0 & 15.9 & 25.2 \\
Occupied Residents & 2704 & 4.0 & 12.1 & 27.5 & 43.6 \\
Registered Unemployment (SEPE) & 414 & 26.1 & 79.1 & 179.5 & 284.5 \\
\hline
\end{tabular}

Source: own elaboration, based on the IGE (2019, Statistical Review) and estimates from his study.

Without public policies to generate substitute employment options, the closure would pose an unsustainable situation for the economic and social viability of As Pontes:

(1) The total impact of the closure would be equivalent to $25.2 \%$ of the resident active population.

(2) The number of employed residents would go from 2704 to 1526 , a reduction of $43.6 \%$.

(3) The number of unemployed people would go from 414 to 1592, an increase of $284.5 \%$.

(4) Only $32.7 \%$ of the resident workforce would remain in employment in the locality, while $34.06 \%$ would become unemployed.

Another significant effect of the closure is the significant reduction in the financial capacity of the municipal government to implement local public policies, since its income will decrease by EUR 3.8 million per year, representing a loss of $45 \%$ of total revenues before the closure.

Finally, in order to better contextualize the impact of the closure, it should be taken into account that As Pontes is a town immersed in a process of demographic decline, derived from industrial and economic erosion that has accelerated since 2007, when coal-mining activity ceased completely. Its natural population balance is regressive and shows a notable aging of the population and a migratory flow in the younger population that cannot find employment opportunities; therefore, the municipality, since the mine closure, has been unable to attract residents and fix the population.

As evidence of this, in 2006, just before the closure of the coal mine, the locality had 4506 salaried workers, while in 2018 the figure fell to 3476, which implies the disappearance of $32.7 \%$ of salaried jobs in that period. In carrying out the mine closure, mostly passive labor policy measures consisting of early retirement payments, severance payments and other compensatory financial instruments were used. These measures proved to be effective in the short term, but inadequate for long-term employment sustainability, as has been shown in the literature in other similar experiences $[3,12,13]$.

Hence, it is important for As Pontes to achieve a truly just transition for the closure of the coal-fired power plant and not just mere voluntarist or empty projects that are ineffective for the affected territories or communities [6]. 


\subsection{Minimum Compensation As Pontes Should Obtain to Neutralize the Initial Impact of the Closure}

In this section, we prepare a synthetic and objective indicator of the circular flow of income lost by As Pontes due to the closure of the plant (Table 2). The availability of this instrument allows us to approach the just transition as a dynamic with two complementary objectives:

(1) To generate relevant information so that the local participatory process can successfully overcome the initial "veil of ignorance" due to the lack of such information [14].

(2) To estimate the compensation for the totality of the initial negative effect of the closure on employment and the internal absorption of the components of GVA in As Pontes [3].

This "veil" exists and was revealed by the results of the survey carried out for this work. Here, we will highlight some significant results on this question, obtained from the responses of the respondents:

(1) The majority (an average of $95.0 \%$ ) considered that, as interested/affected, they were very uninformed about the transition process, since neither the company nor public institutions had adequately informed them about the impact of the closure.

(2) They were aware of the high level of uncertainty (97.8\%) regarding the socioeconomic future of the municipality without creating a positive regulatory framework to reduce it.

(3) They gave the thermal power plant a transcendental role (96.3\%) in the development of the area as an engine of economic activity and employment, while the closure generates negative expectations about citizens and existing economic activities (99.8\%).

(4) A minority of respondents (31.6\%) declared themselves to be supporters of the articulation of a future sustainable economic model based on the sustainable use of the natural resources of the affected area.

Respondents made it clear that (1) they do not consider themselves sufficiently informed and lack a local strategy for the consequences of closure and (2) they do not see adequate real attention from the multilevel governance involved in the specific transition process. They are aware that these shortcomings hinder the implementation of adequate strategic development to achieve the concrete compensatory and sustainable objectives required for the future of the affected territory [1]. Without overcoming these shortcomings with genuinely compensatory objectives, the process will not be truly fair and will only be a mere declaration of intent devoid of effective content [6].

In relation to the above, the variables and data that make up the quantification of the minimum compensation in the case study are set out (Table 4). This provides an objective indicator that takes into account employment and the economy, trying to avoid the reduction of the circular flow of income that existed in As Pontes before the closure. The indicator has to be understood as a flexible proposal, in no way closed, and with the vocation of serving as an informative orientation for the participative process of those affected.

The indicator takes into account the circularity of the economy as it is assuming that the new endogenous, primary and secondary activities will be able to maintain the current level of economic interrelation with the existing exogenous activities so that the overall effect of the closure does not imply a real loss of employment and GVA in As Pontes.

The indicator proposes achieving two objectives: (1) the maintenance of wage income, creating a minimum of 435 new jobs with a gross annual income flow of EUR 12.84 million and (2) the maintenance of property and business income, compensating for the loss of EUR 13.11 million gross per year. 
Table 4. Indicator of the minimum compensation that As Pontes should obtain to achieve a just transition. Objective: to maintain the circular flow of internal income in 2018.

\begin{tabular}{|c|c|c|c|}
\hline \multicolumn{2}{|c|}{$\begin{array}{l}\text { Employment * } \\
\text { Number of Equivalent Jobs }\end{array}$} & \multicolumn{2}{|c|}{$\begin{array}{l}\text { Maintenance of the GVA and Its Components } \\
\text { in Millions of Euros }\end{array}$} \\
\hline Direct Effect Elimination & 108 & Wage Income & 12.84 \\
\hline Indirect Effect Elimination & 327 & Property and Business Income & 13.11 \\
\hline Creation of New Endogenous Jobs & 435 & GVA Endogenous Activities & 25.95 \\
\hline \multirow{3}{*}{ Neutralization of the Circular Effect } & 743 & Wage Income & 20.76 \\
\hline & & Property and Business Income & 20.03 \\
\hline & & GVA of the Circular Effect & 40.79 \\
\hline
\end{tabular}

* The total job destruction in the plant's area of influence has two components: (a) 1178 workers resident in As Pontes and (b) 299 workers resident in neighboring municipalities (20.92\% of the total). It is appropriate to note that in a just transition process, nonresident jobs should not be lost either. Source: own elaboration.

\subsection{A Medium-Term Outlook}

With the decommissioning of the coal power plant, scheduled for July 2021, a transitional period of 3 to 5 years will begin, in which the demolition work will coincide with the construction of new facilities to generate clean energy, announced by Endesa. It seems clear that this will entail a certain amount of work and job creation, but this is a temporary, nonsustainable effect and, therefore, different from the objective of sustainability that compensation must have in the present case.

Taking advantage of this transition period will require strategies to attract and implement sustainable projects, led by "partners" with proactive lobbying capacity that contribute to the socioeconomic and, above all, employment viability of the municipality [3]. All concern, in this area, is necessary to avoid joining some of the cases, noted in the literature, where the energy transition has continued to perpetuate many of the pre-existing status quo of winners and losers [15-17]. The winners turn out to be those who will benefit from cleaner energy sources and new employment and innovation opportunities, while the losers will bear the burdens of adjustment or will not have access to these new opportunities $[15,16,18]$.

Often, policies designed to accelerate the closure of coal-fired power plants rarely specify the detail of what a just transition might entail for the affected territory [8]. This means that those affected, on the one hand, will not be able to successfully overcome the information "veil" and, on the other hand, will not be able to make an active and informed contribution through the participatory process. Hence, it is important that governments and affected people have a tool, such as the one proposed, to quantify compensation for the initial impact and allay local fears about the negative impacts of change in the medium and long term.

The literature finds that, remarkably often, regulatory measures foreseen for coal plant closures have only a minimal content of obligations, forcing local actors, as in the case of study, to invest considerable effort in assessing actual negative impacts and advocating concrete mitigation measures [3,7,17].

When privatization was proposed to respondents as the exclusive mechanism of transition policy, the responses were overwhelmingly negative $(87.3 \%)$, for two main reasons (and similar to those noted by Weller [6]): (1) the increase in social inequalities and long-term imbalances in the affected area and (2) the marginalisation of local community interests and lack of trust in external policy solutions.

Similar to what has been noted in other cases $[1,3,7,12,17,18]$, the significant difficulties faced by the local level in becoming a determining factor in promoting the interests of the affected territory will require external interventions to obtain the financial and labor rewards necessary for its sustainability.

As the literature has pointed out, the scope and implementation of external interventions are related to the existing welfare regime $[7,18]$. In strong welfare states such as Spain, this will must translate into strong socioeconomic support from public institutions 
to implement the specific policies that will be required by the evolution of the particular transition process.

\section{The Effects of Closure and the Need for Public Policies to Achieve a Just Ecological Transition}

Once closure has occurred, achieving successful sustainable economic development planning exceeds the political and financial capacities of local entities, relying on a constellation of "meta-governance" capacities and factors [14]. Our survey results indicate that those affected are (1) aware of their limited capacity to have the necessary instruments to achieve a sustainable future for the affected territory (93.2\%) and (2) lacking confidence that there will be a solution, provided by public administrations $(63.2 \%)$ and/or the current operator $(80.3 \%)$, that will minimize the socioeconomic impact.

Faced with this state of local opinion, it is essential to promote specific means of political action to reverse it positively in terms of a just transition. In this sense, we present several recommendations in order to contribute to the achievement of the aforementioned objective.

\subsection{Recommendations: Multilevel Governance Has to Act as an Environmental Entrepreneur for} the Affected Territory

The results provided by the proposed indicator leave no room for doubt: the initial impact of the closure will have devastating effects on the economy and employment in the territory, which is why it will require strong and decisive support from multilevel governance to compensate for it and to make it sustainable. Two essential reasons stand out:

(1) To help clear the uncertainty associated with the energy and production paradigm shift, to transform it into a framework of assumable business risk.

(2) To help design the concrete framework to overcome the risks and challenges of the huge investment and innovation effort required by the energy paradigm shift and the adequate attention to social and territorial problems [17-19].

It will be key for multilevel governance to assume the position of a large entrepreneur determined to drive clean energy in the name of climate change mitigation. Multilevel governance can do this at a scale and with tools that are not available to private companies, such as favorable taxation or a broad regulatory framework.

Private business investment in new technologies will not be attracted by investments that can only generate benefits for an imprecise "public good". This happens when companies are not able to capture most of the value creation, in which case it is imperative that, at this early stage, multilevel governance does so (see $[7,17,19]$ for case studies).

\subsection{Recommendations: Attend Locally to the Attraction of Investment, with Sustainability Criteria, without Neglecting Individuals and Their Communities}

Given the limitations and difficulties identified for the local level, it will be crucial to have specific policies in place to support the search for and attraction of industrial and technological partners. It is a matter of promoting "meta-governance" to attract those with a proven capacity for success in lobbying for the substantial funds that will be required to implement the projects selected for the territory. It is important to achieve this objective because it is foreseen that the European Next Generation initiative will generate a context of significant public-private cooperative participation and a highly competitive awarding regime $[7,18]$.

The model that is finally chosen must necessarily implement complementary measures of action in the areas where we have noted the most notable deficiencies $[3,7,12,17]$ :

(1) Local productive sectors and groups at risk.

(2) Population fixation and job creation.

(3) The promotion of diversification and productive specialization consistent with the socioeconomic context. 
(4) The restoration of the tax capacity of local government, diminished by the closure of the plant, for the sustainability of the provision of local public goods and services.

4.3. Recommendations: Use the "Persuasiveness" of the Regulatory Framework to Reinforce the Achievement of Intended Local Objectives

An analysis of the specific Spanish regulation reveals the existence of two instruments of public intervention, which have a great capacity for effective "persuasion" when it comes to reinforcing policies aimed at achieving specific objectives for the territory concerned [18].

On the one hand, the Ministry for Ecological Transition and the Demographic Challenge has the power to establish procedures and requirements for granting all or part of the evacuation access capacity of the grid nodes affected by the closure to new generation facilities using renewable energy sources.

On the other hand, this Ministry has the legal capacity to regulate the granting of new concessions for the private use of water to new initiatives and projects in the geographical area where the industrial facility being closed was located, under economic, social and environmental criteria.

\subsection{Recommendations: Promote Multilevel Institutional Collaboration to Eliminate Structural Deficiencies in the Territory}

It is essential to implement different lines of aid and funding that consolidate the collaboration between the central and subcentral administrations, with the aim of supporting projects that require specific policies to overcome structural deficiencies that have been observed in the territory due to the closure of the plant $[1,3,7,17]$.

The results of the survey carried out on the state of the participatory process in As Pontes have revealed notable shortcomings in several important lines of action for specific public policies: (1) insufficient provision of sustainable and inclusive employment, with particular attention to women, young people, people over 45, people with disabilities and groups in vulnerable situations and at risk of social exclusion; (2) lack of instruments to boost local productive factors and unique economic benefits for the area of As Pontes; (3) need to restore degraded spaces and lack of support for the circular economy; and (4) significant shortcomings in the field of innovation, with the emphasis on processes, products, marketing and organizational aspects.

\subsection{Discussion}

In Spain, the CTJs foresee that mitigation will be limited to the provision of sufficient compensation to achieve the complete elimination of the negative impact on employment. This is the variable that the CTJs consider fundamental for attributing to an energy and ecological transition policy the qualification of "fair".

However, the results of our study suggest that these Conventions fall short in their objectives, as they suffer from a lack of contextualization towards the territory concerned, considering only direct and indirect effects without any mention of the circular effect on employment and internal income absorption.

Overcoming this shortcoming requires political will to implement public policies articulated in a comprehensive, far-sighted action plan, which achieves the maintenance and creation of sustainable economic activity and employment in the affected territory [1,18].

To be effective, public policies will require a wide range of measures, which, for the time being, are only planned and have not yet been implemented or financially endowed [12,18].

Finally, if the technology being renounced (electricity production in conventional coal-fired power plants) means more quality jobs than the alternatives proposed (green hydrogen, wind energy, etc.), the new energy projects must necessarily be accompanied by complementary industrial plans in the territories concerned [1,3]. This is the only way to achieve broad acceptance of the transition process and to successfully complete a change in the economic and social model, based on sustainable growth and the protection of the most vulnerable groups $[7,18]$. 


\section{Conclusions}

In relation to the closure of the power plant in the case of study, our proposal has made it possible to (1) specify and contextualize the effects into which the initial impact of the closure can be divided, including the circular effect, and (2) obtain an indicator of the minimum compensation that would be necessary to neutralize this impact, based on the internal absorption of income that the territory makes from the total production carried out in the territory.

The initial impact of the closure of the As Pontes coal-fired power plant, derived from the "energy and ecological transition" process applied in Spain, in the absence of any public mitigation policy, would have a direct effect of $9.1 \%$ of the total impact, an indirect effect representing $27.8 \%$ of the total impact and a circular effect equivalent to $63.1 \%$ of the total impact.

In 2019, the year officially designated for calculating the effects of the closure of the coal plant, the initial impact of the closure, in the absence of any type of substitute activity, would be devastating for the economy and employment in As Pontes. In terms of internal absorption of goods and services, it would register annual percentage losses of (1) $49.1 \%$ of total production, (2) $45.6 \%$ of GVA, (3) $44.3 \%$ of salary remunerations and (4) $46.6 \%$ of property and company income.

In terms of employment, 1178 resident jobs would be lost (108 direct, 327 indirect and 743 induced), and a further 299 jobs would be lost in the area of influence of the plant outside the municipality.

With regard to the contextualization of lost employment, only $32.7 \%$ of the resident labor force would keep their jobs in the locality, while the number of employed residents would decrease by $43.6 \%$ and the number of unemployed would increase by $284.5 \%$.

In addition to the implementation of new investment projects, the decarbonization process will have to be accompanied by compensation in terms of employment, involving the creation of a minimum of 435 workers with salaries equivalent to those currently employed and a generation of GVA of EUR 26 million per year, in constant euros, at the time of requesting the closure of the plant.

The challenges generated by the complexity of the transition process and the need to obtain satisfactory solutions from a sustainability perspective will require strong and decisive support from multilevel governance for the affected territory. It will be essential to create and provide specific measures to address the extraordinary risks and challenges of the investment effort, which our work has highlighted, in order to compensate for the magnitude of the impact of the closure and to achieve the socioeconomic and environmental sustainability of the affected territory.

Author Contributions: Conceptualization, A.J.P.-D. and F.G.-L.; methodology, A.J.P.-D. and F.G.-L.; data curation, M.E.-C. and F.M.-B.; formal analysis, A.J.P.-D., M.E.-C. and F.M.-B.; funding acquisition, A.J.P.-D.; investigation, F.G.-L. and M.E.-C.; methodology, A.J.P.-D. and F.G.-L.; writing-original draft, A.J.P.-D.; writing-review \& editing, F.M.-B. All authors have read and agreed to the published version of the manuscript.

Funding: This research was funded by MITECO Ministry (Government of Spain) and the As Pontes City Council.: 2019/C004/000030.

Institutional Review Board Statement: Not applicable.

Informed Consent Statement: Not applicable.

Data Availability Statement: Not applicable.

Conflicts of Interest: The authors declare no conflict of interest. 


\section{References}

1. Atteridge, A.; Strambo, C. Seven Principles to Realize a Just Transition to a Low-Carbon Economy. In SEI Policy Report; June 2020. Available online: https://cdn.sei.org/wp-content/uploads/2020/06/seven-principles-for-a-just-transition.pdf (accessed on 7 May 2021).

2. Fouquet, R. Historical energy transitions: Speed, prices and system transformation. Energy Res. Soc. Sci. 2016, 22, 7-12. [CrossRef]

3. Haggerty, J.H.; Haggerty, M.N.; Roemer, K.; Rose, J. Planning for the local impacts of coal facility closure: Emerging strategies in the U.S. West. Resour. Policy 2018, 57, 69-80. [CrossRef]

4. Aung, M.T.; Strambo, C. Distributional Impacts of Mining Transitions: Learning from the Past. In SEI Working Paper; 2020. Available online: https://cdn.sei.org/wp-content/uploads/2020/04/distributional-impacts-of-mining-transitions-1.pdf (accessed on 3 May 2021).

5. Sommer, E. Justice for All: John Rawls Theory of Justice and the Green New Deal. El Rio Stud. Res. J. $2018,1,58-65$.

6. Weller, S.A. Just transition? Strategic framing and the challenges facing coal dependent communities. Environ. Plan. C Politics Space 2019, 37, 29-316. [CrossRef]

7. Krawchenko, T.; Gordon, M. How Can We Manage a Just Transition? A Comparative Review of Policies to Support the Just Transition from Carbon Intensive Industries; Institute for Integrated Energy Systems; University of Victoria: Victoria, Canada, 2021.

8. Harrahill, K.; Douglas, O. Framework development for 'just transition' in coal producing jurisdictions. Energy Policy $2019,134$. [CrossRef]

9. Instituto Galego de Estatística. Revisión Estatística (RE19); Instituto Galego de Estatística: Santiago de Compostela, España, 2021.

10. Fernández-Macho, J.; López, P. Matrices de Contabilidad Social: Una panorámica. Ekonomiaz 2004, 3, $132-163$.

11. Fuentes Salazar, P.; Alejandro Cardenete, M.; Vega Cervera, J.A. Impacto Económico de la Clausura de Una Planta Nuclear, Almaraz (España); Orkestra-Instituto Vasco de Competitividad, Fundación Deusto: Bilbao, España, 2013.

12. Goetz, S.; Partridge, M.; Stephens, H. The Economic Status of Rural America in the Trump Era. MPRA Paper \#77830. 2017. Available online: https://mpra.ub.uni-muenchen.de/77830/1/MPRA_paper_77830.pdf (accessed on 28 May 2021).

13. Sartor, O. Implementing Coal Transitions. Insights from Case Studies of Major Coal-Consuming Economies; IDDRI: Paris, France, 2018.

14. Morrison, T.; Lane, M.B.; Hibbard, M. Planning, governance and rural futures in Australia and the USA: Revisiting the case for rural regional planning. J. Environ. Plan. Manag. 2014, 58, 1601-1616. [CrossRef]

15. Carley, S.; Konisky, D.M. The justice and equity implications of the clean energy transition. Nat. Energy 2020, 5, 569-577. [CrossRef]

16. Darnall, N.; Jolley, G.J. Involving the Public: When Are Surveys and Stakeholder Interviews Effective? Rev. Policy Res. 2004, 21, 581-593. [CrossRef]

17. Jolley, G.J.; Khalaf, C.; Michaud, G.; Sandler, A.M. The economic, fiscal, and workforce impacts of coal-fired power plant closures in Appalachian Ohio. Reg. Sci. Policy Pr. 2019, 11, 403-422. [CrossRef]

18. Maguire, D.; Shaw, C. Fair Energy Transitions for All_Literature Review; Climate Outreach: Oxford, UK, 2021. Available online: https:/ / fair-energy-transition.eu/wp-content/uploads/2021/02/FETA-Literature-Review_final.pdf (accessed on 13 May 2021).

19. Mazzucato, M. The Entrepreneurial State; Anthem Press: London, UK, 2014. 